овладение языком и культурой страны изучаемого язика). - Vestnik KuzGTU. - №3. Print.

Safonova, V. V. (1998). Problemy sotsiokulturnogo obrazovaniya $v$ yazykovoi pedagogike. Kulturovedcheskiye aspekty yazykovogo obrazovaniya (Сафонова В.В. Проблемы социокультурного образования в языковой педагогике. Культуроведческие аспекты языкового образования). - Moscva Yevroshkola. $-63 \mathrm{p}$.
Sharapova, S. I. (2009). Kharakteristika chteniya kak opostedovannogo sredstva kommunikatsii (Шарапова С. И. Характеристика чтения как опосредованного средства коммуникации). - Vestnik KGU. - №1. Print.

Shovkovyi, V. M. (2011). Metodychna systema navchannia davnyogretskoi movy maibytnih filologiv na zasadah germenevtychnogo pidhody (Шовковий В. М. Методична система навчання давньогрецької мови майбутніх філологів на засадах герменевтичного підходу). Diss. Kyiv. Print.

\title{
DEVELOPING SOCIO-CULTURAL COMPETENCE IN PHILOLOGY MAJORS THROUGH POETRY READING: APPROACHES AND PRINCIPLES
}

\section{Nataliia Semian}

Department for Teaching Methodology of Ukrainian and Foreign Languages and Literatures, Institute of Philology, Taras Shevchenko National University of Kyiv, Kyiv, Ukraine

\section{Abstract}

Background: The need to develop students' socio-cultural competence is grounded in the socio-cultural framework which places a meaningful emphasis on interpersonal interaction as a significant motivating force of human learning and development. In this theoretical framework, 'approaches' and 'principles' of teaching foreign languages (FL) are viewed as the two essential methodology concepts affecting both FL learning and building socio-cultural competence. In a regular classroom, the suggestions to enhance socio-cultural competence through reading poetry are voiced. Socio-cultural implications for classroom activities include using specific approaches and principles which help identify a fundamental relationship between language and culture. Teaching a FL through poetry enables students to perceive the nature of the relationship between language and culture.

Purpose: The article aims at selecting approaches to developing students' socio-cultural competence in reading through poetry works. It presents the definitions, determines principles as well as provides analysis of the approaches in terms of their implementation in FL training.

Results: The role played by culture and language in human development is an essential aspect of this research. The findings of the study prove that socio-cultural competence in reading emphasizes the interdependence of social and individual processes in the construction of FL knowledge. As a result of the research, this article shows that the theoretical basis is formed by the following approaches and principles in developing students' socio-cultural competence in reading through poetry works: competency building, hermeneutic, communicative and country-study approaches. The article gives detailed analysis of each approach. The approaches and principles mentioned provide developing socio-linguistic competence in reading and can be integrated in the process of studying.

Discussion: Authentic English poetry provides invaluable information about the life of British society. However, before using authentic poems in the classroom, they should be carefully selected against certain criteria of building socio-cultural competence in reading through poetry as well as pedagogical conditions which provide developing socio-cultural competence. Attention should be paid to motivate students' interest towards the target culture enabling them to be culturally adequate speakers of English.

Keywords: socio-cultural competence, teaching reading principle, interpretation, culture-specific items, poetry work, language tools.

\section{Vitae}

Nataliia Semian, Department for Teaching Methodology of Ukrainian and Foreign Languages and Literatures, Institute of Philology, Taras Shevchenko National University of Kyiv. Her areas of research interests include communicative strategies, sociolinguistics, contemporary British poetry.

Correspondence: semian.nv@gmail.com 


\section{З ДОСВІДУ НАВЧАННЯ МОВ У СЕРЕДНІЙ ТА ВИЩІЙ ШКОЛАХ}

ОЛЬГА ДРАГІНДА (м.КИїв)

ORCID: 0000-0002-1080 -4817

\section{НАВЧАННЯ ЛЕКСИКИ: 3 ДОСВІДУ ВИКЛАДАННЯ ДИСЦИПЛІНИ «ЗАГАЛЬНИЙ КУРС ЗАХІДНОЄВРОПЕЙСЬКОЇ МОВИ» ДЛЯ СТУДЕНТІВ І КУРСУ СПЕЦІАЛЬНОСТІ «СХІДНА ФІЛОЛОГІЯ»}

\author{
Тема заняття: EVERY GENERATION IS A \\ PRODUCT OF THEIR TIMES \\ Тип заняття: практичне, комбіноване \\ Цілі заняття: \\ Практичні: \\ - активізувати вживання лексики з теми \\ заняття; \\ - розвивати вміння розуміти на слух ос- \\ новний зміст аутентичного тексту; \\ - розвивати вміння стисло переказувати \\ текст \\ - навчити виокремлювати суттєву інфрор- \\ мацію; \\ - розвивати вміння письмово передавати \\ власну думку.
}

\section{Освітні:}

- розширити знання студентів про особливості представників різних поколінь та фрактори, що вплинули на їхнє формування;

- розширити знання студентів про відомих представників різних поколінь в англомовних країнах.

\section{Розвиваючі:}

- розвивати пізнавальні здібності студентів;

- розвивати вміння аналізувати та систематизувати нову інфрормацію;

- розвивати готовність до участі в іншомовному спілкуванні;

- розвивати вміння логічного викладення думок.

\section{Виховні:}

- виховувати позитивне ставлення до іноземної мови та культури;

- формувати доброзичливе та толерантне ставлення до представників інших поколінь;

- виховувати самостійність та активість;

- формувати інтерес і позитивну мотивацію до навчання;
- прищеплювати вміння аналізувати, думати, висловлювати свою точку зору.

\section{Хід заняття}

1. Організаційний момент: (2 хв.)

- повідомлення теми заняття;

- повідомлення мети заняття.

2. Актуалізація теми. Мовленнєва зарядка. (3 хв.)

3. Аудіювання англомовної лекції про покоління. (35 хв.)

а) підготовка до аудіювання; (10 хв.)

б) робота над усуненням можливих лексичних труднощів під час аудіювання; (5 хв.)

в) презентація аудіозапису і контроль розуміння прослуханого. (20 хв.)

4. Робота над текстом «The Generation Guide - Millennials, Gen X, Y, Z and Baby Boomers» (27хв.)

а) читання тексту; (7 хв.)

б) виконання післятекстових завдань. $(20$ хв.)

5. Письмо (10 хв.)

6. Підведення підсумків заняття. Пояснення домашнього завдання.

Оцінювання знань студентів та рівня ссрормованості іншомовної комунікативної компетентності. (3 хв.)

\section{Методичне забезпечення}

1. Global.Upper-Intermediate Coursebook / ed. by Lindsay Clandfield and Rebecca Robb Benne. - Macmillan, 2014. - 158 p.

2. The Generation Guide - Millennials, Gen $\mathrm{X}, \mathrm{Y}, \mathrm{Z}$ and Baby Boomers [Електронний peсурс]. - Режим доступу: http://fourhooks.com/ marketing/the-generation-guide-millennials-gen$x-y-z-a n d-b a b y-b o o m e r s-a r t 5910718593 /$

\section{Оснащення}

1. Комп'ютер / програвач.

2. Аудіозапис. 


\section{3. Роздатковий матеріал.}

\section{Розгорнутий план-конспект заняття}

1. Організаційний момент: повідомлення теми та мети заняття.

Teacher: Hello! Nice to see all of you again! Today we are going to discuss the most important traits of different generations.

\section{2. Мовленнєва зарядка.}

Teacher: You are going to listen to a lecture which starts off with the words 'Every child, every generation is a product of their times.' Do you think this statement is true?

Режим роботи: T- S1, T-S2 і т.д.

\section{3. Аудіювання англомовної лекції про покоління.}

Робота з базовим навчальним посібником Global. Upper-intermediate, p.60.

Teacher: Generation is all the people of about the same age. Children are shaped by the society into which they are born: every generation of children is greatly affected by the beliefs, ideas, laws, events of the time and place in which they grow up.

affluence (affluent society)
strong-minded
downside

to stand on one's own two feet technologically savvy

\section{Режим роботи: T-S1, T-S2, T-S3 і т.д.}

\section{Suggested answers:}

Affluence - abundance of money, property or any material goods, wealth - достаток, фрінансове благополуччя

Affluent society - having plenty of money, so that one can afford to buy expensive things, live in a nice house etc. - багате суспільство

Strong-minded - not easily influenced by other people to change what you believe or want той, що самостійно мислить

Downside - the negative side - негативний аспект, мінус

To stand on one's own two feet - to be able to earn what you need without help from others бути незалежним

Technologically savvy - having practical knowledge of and ability to use modern technology, especially computers - технологічно 'підкований' а) підготовка до аудіювання;

Task: You'll work in pairs. Decide which things give a generation their identity (the political situation, the economic situation, important historic events, scientific and technological developments, population trends, fashion, music) and to rank them in order of importance. You'll have some minutes to do it and then we'll compare your results with the results of other pairs. Do you agree with their results?

Режим роботи: S1- S2, S3-S4 і т.д; T-S1S3-S5 і т.д.;

б) робота над усуненням можливих лексичних труднощів під час аудіювання;

Teacher: Now we need to specify the meaning of some words that are used in the lecture you are going to listen. On the sheets of paper, you've received, there is a list of words, which may be either unfamiliar to you or useful for our further discussion. Let's elicit their meaning and probably translate some of them for you to better comprehend the lecture.

Task: Read a word / word combination and explain its meaning:

multitasking

defining characteristic

consumer culture

prime motivation

Multitasking - a person's ability to do more than one thing at a time - багатозадачність

Defining characteristic - a particular feature or quality that differentiates something from other things - визначальна характеристика

Consumer culture presupposes that the economy is focused on the selling of consumer goods and the spending of consumer money; an emphasis is on lifestyle and using material goods to attain happiness and satisfaction; i.e. consumer cultures encourage consumers to spend money on goods - споживацька культура

Prime motivation - the most important reason for doing something - основна мотивація.

в) презентація аудіозапису і контроль розуміння прослуханого.

Task 1. Listen to the lecture and answer the questions:

1. What generation is being discussed? When were they born? 
2. Which of the things have shaped this generation, according to the speaker?

Режим роботи: T-S1, T-S2, T-S3 і т.д.

Suggested answers:

1. Generation $Y$, the 'net generation'. Born between the late 1970s and late 1990s.

2. The economic situation (growing up in relative affluence); scientific and technological developments (computers and the Internet); population trends (towards smaller families). Fashion and music are not explicitly mentioned but could be included under consumer trend, and political influences are implicit.

Task 2. Listen again. Say whether the statements are true or false:

Generally speaking, this generation ...

1 is fairly selfish.

2 is independent.

3 can do several things at once.

4 lacks new ideas.

5 crosses national boundaries.

6 is loyal to employers.

Режим роботи: T-S1, T-S2, T-S3 і т.д.

Suggested answers: $1-\mathrm{T}, 2-\mathrm{F}, 3-\mathrm{T}, 4-\mathrm{F}$, $5-\mathrm{T}, 6-\mathrm{F}$.

\section{Audioscript (Track 1.72):}

Every child, every generation is a product of their times. And this is certainly true for the net generation, often referred to as 'Generation Y'. These children were born from the late 1970s to the late 1990s. Growing up in relative affluence in many parts of the world, with abundant attention front family and friends, this generation is strongminded, self-confident - and sometimes rather self-centered.

Many Generation $Y$ children in more affluent societies have fewer brothers and sisters than in previous generations or are only children, and they are often quite spoilt and protected by their parents.

In China, for example, these children are known as 'Little Emperors'. In general, Generation $Y$ is better dressed, better fed and better looked after than previous generations. The downside is that many of this generation are not used to standing on their own two feet.

Largely due of course to being the first generation to grow up with computers and the internet, this generation is well-informed and technologically - savvy. While older generations are still getting used to sending emails, members of Generation $\mathrm{Y}$ are competent and constant users of mobile phones, instant messaging, music downloads and social networking sites - and are used to multitasking - using different technologies at the same time and switching between tasks. They are creative, publishing their own blogs, websites, videos and music. And they are part of a global online community with access to information and other young people from all over the world.

Consumer culture is another defining characteristic of Generation Y. Its members are financially more secure than previous generations who have had to get used to consumerism. In India, for example, where half of the population is under 25 , young people no longer see a good education and a permanent job as their main aim in life. As the service industry booms, so young people are learning to adapt to a more flexible, easygoing job culture where jobs are changed on a regular basis and where money is the prime motivation - money that can be used to buy consumer products such as cars and electronic equipment.

\section{4. Робота над текстом «The Generation Guide - Millennials, Gen X, Y, Z and Baby Boomers»}

а) читання тексту;

Task: Read a description of one of the 5 generations and choose the most important information.

\section{The Greatest Generation:}

Born between 1901 - 1924, they are those who experienced the Great Depression and World War II in their adulthood, all leading to strong models of teamwork to overcome and progress. They are our great-grandfathers, growing up without modern conveniences like refrigerators, electricity and air conditioning. They are the generation that remembers life without airplanes, radio, and TV.

The Silent Generation: Also known as Builders or Maturists, born in between $1924-1945$, coming of age during the postwar happiness. Jazz, Swing, Frank Sinatra, Gone With The Wind and Mickey Mouse generation. We are talking about pre-feminism, staying at home moms and men pledging their loyalty to a lifetime job. The children who grew up during this time worked 
very hard and kept quiet. It was commonly understood that children should be seen and not heard.

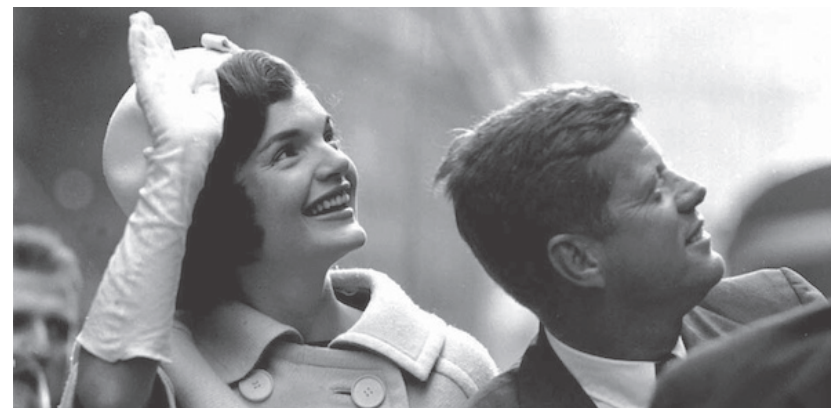

While there were many civil rights leaders like Martin Luther King, Jr., Robert F. Kennedy or artists like Andy Warhol, Clint Eastwood, Bob Dylan, John Lennon, Ray Charles, Jimi Hendrix, the "Silents" focused on their careers rather than on activism, and people were largely encouraged to conform with social norms.

Baby Boomers: On this, no one says it better than The Telegraph: "Those born in the years after World War II, when there was - thanks to soldiers returning home - a significant spike in births, both in America and in Britain. These are the men and women who tuned in, got high, dropped out, dodged the draft, swung in the Sixties and became hippies in the Seventies. Some, like Bill Clinton, made it to the White House. Idealistic and uncynical, this was the generation that fought the

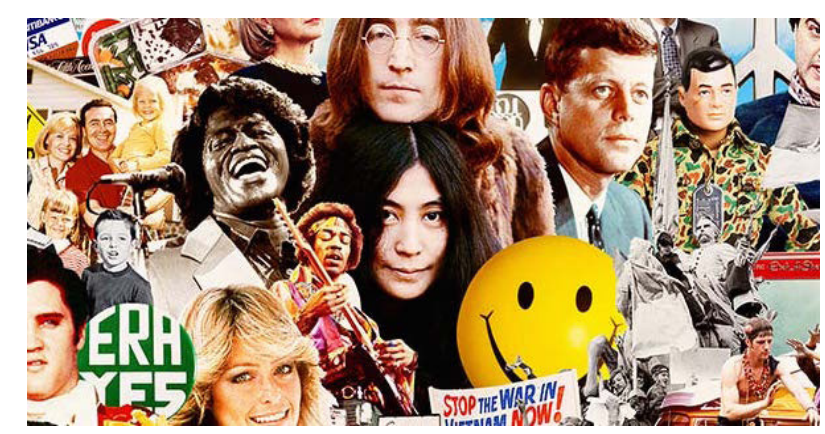

cold war and smashed down the Berlin Wall."

The generation can be segmented into two: The Leading-Edge Baby Boomers are individuals born between 1946 and 1955, those who, for US, came of age during the Vietnam War era. The other half of the generation was born between 1956 and 1964 and is called Late Boomers, or Trailing-Edge Boomers.

It is the Rock and Roll, Elvis, Beatles, Woodstock, Miniskirts, Barbie generation. The first two-income household generation, the first TV generation, the first divorce generation, where divorce was beginning to be accepted as a tolerable reality. The first tolerant generation. Envision technology and innovation as requiring a learning process.

Generation X: Born between 1965 and 1980, they grew up street-smart but isolated, often with divorced or career-driven parents. Most remember being in school without computers and then after, the introduction of computers in middle school or high school. More interested in philosophizing than settling with a long-term career and family, they tend to commit to self and average 7 career changes in their lifetime, unlike earlier generations. Late to marry and quick to

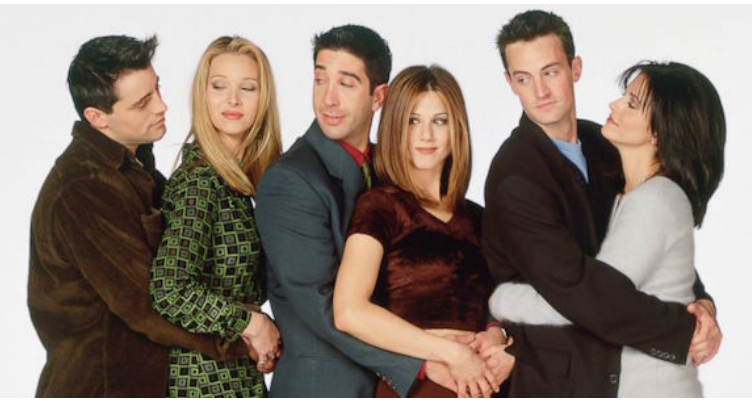

divorce....many single parents.

Gen Xers are often called the MTV Generation. They experienced the emergence of music videos, new wave music, electronic, glam rock, heavy metal, punk, grunge and hip hop. It is the Nirvana, U2, Madonna, Friends, Beverly Hills 90210, PC generation.

They are into labels and brand names. They want what they want and want it now, but struggle to buy, and most are deeply in bank and credit card debt. With a high level of skepticism, "what's in it for me?" defines them as consumers. Referred to as Digital Immigrants.

Generation $\mathbf{Y}$ or Millennials: They are individuals born between 1980 and 1995. Known as sophisticated, technology wise, immune to most traditional marketing and sales pitches, they've seen it all and been exposed to it all since early childhood.

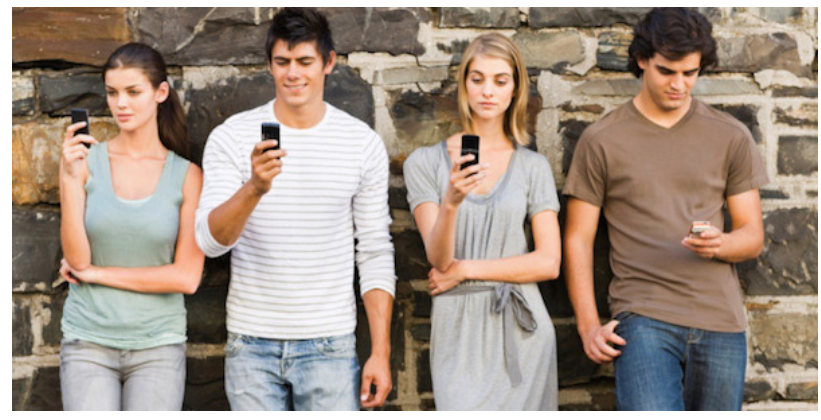

